\title{
Properties of the major non-specific endonuclease from the strict anaerobe Fibrobacter succinogenes and evidence for disulfide bond formation in vivo
}

\author{
Shawn R. MacLellan† and Cecil W. Forsberg
}

\begin{abstract}
Author for correspondence: Cecil W. Forsberg. Tel: +1 5198244120 ext. 3433. Fax: +1 5198371802. e-mail: cforsber@uoguelph.ca
\end{abstract}

Department of Microbiology, University of Guelph, Guelph, Ontario, Canada N1G 2W1
DNase $A$ is a non-specific endonuclease of Fibrobacter succinogenes. The enzyme was purified to homogeneity and its properties studied both in vitro and in vivo. Magnesium but not calcium was essential for nucleolytic activity. Manganese ions substituted for magnesium but were less stimulatory. DNase A activity was markedly inhibited by either $\mathrm{NaCl}$ or $\mathrm{KCl}$ at concentrations greater than $75 \mathrm{mM}$. The enzyme had a temperature optimum of $25^{\circ} \mathrm{C}$ and a pH optimum of about 7.0. Values for $K_{\mathrm{m}}$ and $K_{\text {cat }}$ were determined to be $61 \mu \mathrm{M}$ and $330 \mathrm{~s}^{-1}$ respectively, with a catalytic efficiency approximately threefold greater than bovine pancreatic DNase I, but 10-fold less than the Serratia marcescens NucA. DNase A was localized to the periplasm and probably exists as a monomeric species. The enzyme possessed one or more disulfide bonds. In the reduced form it had an apparent mass of $33 \mathrm{kDa}$, while in the oxidized form it was $29 \mathrm{kDa}$ as estimated by SDS-PAGE. Reduction of the disulfide bonds by dithiothreitol with or without subsequent alkylation by iodoacetamide strongly inactivated the enzyme. DNase $A$ accumulated in vivo had an apparent mass of $29 \mathrm{kDa}$, indicating that it was in an oxidized form. This is the first indication in a strict anaerobe of a functional periplasmic disulfide bond forming system, phenotypically similar to Dsb systems in facultative and aerobic bacteria.

Keywords: endonuclease, anaerobe, disulfide bond, Fibrobacter succinogenes

\section{INTRODUCTION}

Fibrobacter succinogenes has been cited as an important cellulose degrading micro-organism in the bovine rumen (Chesson \& Forsberg, 1997; Halliwell \& Bryant, 1963) and one of the most cellulolytic organisms isolated from any environment (Weimer, 1996). Although numerous cellulolytic and hemicellulolytic enzymes have been characterized, continued research into deciphering the mechanisms by which $F$. succinogenes degrades plant cell wall polymers has been hampered by the lack of a gene transfer system. Cited as a possible barrier to transformation by DNA, the DNase A protein was previously detected in partially purified cell lysates and characterized as a non-specific endonuclease (Lee et al., 1992). The enzyme can cleave double and single stranded

†Present Address: Department of Biology, McMaster University, Hamilton, Ontario, Canada L8S 4K1.
DNA, and F. succinogenes genomic DNA, to fragments primarily $8-11 \mathrm{nt}$ in length. In a continued effort to characterize this enzyme and investigate its possible negative influence on transformation by DNA, we have purified DNase A to homogeneity from F. succinogenes cells and report some catalytic properties of the enzyme. In addition, we have had the opportunity to extend our investigation into aspects of disulfide bond formation in F. succinogenes because DNase A migrates more slowly during SDS-PAGE when the disulfide bonds are reduced, and the reduced and oxidized states of the enzyme can be readily resolved by gel electrophoresis. We are unaware of any disulfide bond formation studies using strict anaerobes and unlike the organisms traditionally used in such studies, $F$. succinogenes is a strictly anaerobic bacterium that requires a well-poised low-redox environment for growth. The question therefore was whether an extracytoplasmic enzyme of this bacterium would be efficiently oxidized in vivo. 


\section{METHODS}

Bacterial strain and growth. F. succinogenes strain S85 was cultured in a liquid medium (Scott \& Dehority, 1965) with glucose as the carbon source at a concentration of $0.5 \%(\mathrm{w} / \mathrm{v})$, and with cysteine- $\mathrm{HCl}$ at $5.7 \mathrm{mM}$ as the reducing agent. Inoculation of cultures was conducted under a stream of oxygen-free $\mathrm{CO}_{2}$ and vessels were tightly stoppered to maintain anaerobicity. Unstoppered vessels and Petri plates containing medium solidified with $1.5 \%(\mathrm{w} / \mathrm{v}$ ) agar (Difco Laboratories) were manipulated in an anaerobic chamber (Coy) under a $90 \%(\mathrm{v} / \mathrm{v}) \mathrm{CO}_{2}$ and $10 \%(\mathrm{v} / \mathrm{v}) \mathrm{H}_{2}$ atmosphere. The growth temperature was $37^{\circ} \mathrm{C}$.

Cellular fractionation and subcellular distribution of enzyme activities. Cells were fractionated by a process based on that of Gong \& Forsberg (1993). Cells were collected by centrifugation $\left(3000 \mathrm{~g}, 15 \mathrm{~min}, 4^{\circ} \mathrm{C}\right)$ from a $120 \mathrm{ml}$ volume of culture after growth for $18 \mathrm{~h}$ to a density of $0.8 \mathrm{mg}$ cells (dry wt) $\mathrm{ml}^{-1}$. The cell-free extracellular culture fluid was retained. The cell pellet was mixed to form a thick slurry and $50 \mathrm{ml}$ icecold distilled water was added. The cells were vigorously resuspended in the water and stored on ice for $15 \mathrm{~min}$, after which time they were again collected by centrifugation. The cell-free supernatant was retained and the cell pellet was again mixed to form a thick slurry, and then vigorously suspended in $50 \mathrm{ml} 50 \mathrm{mM}$ Tris/HCl (pH 7.5) buffer containing $0.5 \mathrm{M}$ $\mathrm{NaCl}$. After incubation on ice for $15 \mathrm{~min}$, the cells were collected by centrifugation, the supernatant was retained, and the Tris $/ \mathrm{HCl} / \mathrm{NaCl}$ wash was repeated two additional times. The supernatants from the distilled water wash and the three salt washes that contained periplasmic contents and outer membrane were pooled (fraction 1). The treated cells were suspended in $20 \mathrm{ml} 50 \mathrm{mM}$ Tris $/ \mathrm{HCl}(\mathrm{pH} 7.5)$ and subjected to three passes through a French Press (16000 p.s.i. [110400 kPa], fraction 2). A $20 \mathrm{ml}$ volume of cell culture (including the culture supernatant) abstracted from the original overnight culture was subjected to three passes through a French Press and this fraction was labelled whole cell lysate. All fractions were concentrated ninefold relative to each originating culture volume through a PM-10 membrane (Amicon, $10 \mathrm{kDa}$ molecular mass cut-off). The concentrated samples were centrifuged $\left(16000 \mathrm{~g}, 20 \mathrm{~min}, 4^{\circ} \mathrm{C}\right)$, decanted and stored on ice at $4^{\circ} \mathrm{C}$. From fractions 1 and $2,1 \mathrm{ml}$ aliquots were retained and the remaining volumes were ultracentrifuged $\left(100000 \mathrm{~g}, 4^{\circ} \mathrm{C}\right)$ for $2.5 \mathrm{~h}$ to sediment membranous materials. The cytoplasmic membranes from fraction 2 were resuspended in $1 \mathrm{ml} 20 \mathrm{mM}$ PIPES ( $\mathrm{pH} \mathrm{6.8)} \mathrm{buffer} \mathrm{and} \mathrm{diluted}$ when assayed for enzyme activities. A smaller pellet was collected from fraction 1, and both this pellet (labelled outer membrane) and the supernatant (labelled periplasm) were handled as described for the cytoplasm and cytoplasmic membrane samples. Equivalent volumes of the fractions and the whole cell lysate were assayed for nuclease activity (microtitre plate assay), glutamate dehydrogenase (cytoplasmic marker), succinate dehydrogenase (cytoplasmic membrane marker) and cellobiosidase (periplasmic marker), and for total protein using the method of Bradford (1976).

Nuclease assays. Three different methods were used to evaluate nuclease activity. Nuclease activity was compared between crude samples by monitoring the decrease in fluorescence of a herring testes DNA/ethidium bromide solution when the DNA was depolymerized in a microtitre plate assay (Ball et al., 1990). After incubation, the microtitre plate was viewed over a UV transilluminator and the titre of nuclease activity was scored visually by recording the last well in a series that demonstrated a complete loss of ethidium bromide fluorescence due to DNA degradation. In some cases, in- complete loss of fluorescence in the last well in a series would be scored as one half loss of fluorescence. Activity was expressed as the inverse of the titre. Nuclease activity in the presence of various salts could also be qualitatively demonstrated by using agarose gel electrophoresis and ethidium bromide staining to detect the loss of a DNA substrate after exposure to nuclease. Gels contained $0.8 \%$ agarose and the running buffer was TBE $(45 \mathrm{mM}$ Tris-borate, $2 \mathrm{mM}$ EDTA, $\mathrm{pH} 8.0$ ). The hyperchromicity (Kunitz) assay was used for pure or partially purified protein samples and detects the increase in absorbance by DNA at $260 \mathrm{~nm}$ when the polymer is depolymerized to nucleotides or short oligonucleotides (Friedhoff et al., 1996; Kunitz, 1950). Assays were conducted with a reagent mixture containing $50 \mathrm{mM}$ Tris/ $\mathrm{HCl}(\mathrm{pH} 7 \cdot 5)$, $20 \mathrm{mM} \mathrm{MgCl}{ }_{2}$ and $40 \mu \mathrm{g}$ herring testes DNA ml${ }^{-1}$ (Sigma), unless otherwise noted. The reaction volume was $450 \mu \mathrm{l}$ and $0.25 \mu$ g purified DNase A was used per assay unless otherwise noted. Assays were conducted in triplicate and regression curves were generated from the linear portion of each progress curve. Specific activity was reported as $\Delta A_{260} \min ^{-1}$ (mg protein $)^{-1}$. Assays were conducted at $22^{\circ} \mathrm{C}$ unless otherwise noted. The influence of $\mathrm{pH}$ on nuclease activity was tested using a three-buffer mixture $\left[0 \cdot 1 \mathrm{M}\right.$ ACES $\left(\mathrm{p} K_{\mathrm{a}}=6 \cdot 65\right)$, $0.052 \mathrm{M}$ Tris $\left(\mathrm{pK}_{\mathrm{a}}=8.00\right), 0.052 \mathrm{M}$ ethanolamine $\left(\mathrm{p} K_{\mathrm{a}}=\right.$ 9.47)] at $30{ }^{\circ} \mathrm{C}$ (Ellis \& Morrison, 1982). Each experiment was conducted at least twice.

Other enzyme assays. With the exception of the nuclease assays previously described, one unit is defined as the conversion of $1 \mathrm{nmol}$ substrate $\mathrm{min}^{-1}$. Specific activity was defined as units ( $\mathrm{mg}$ protein $)^{-1}$. Glutamate dehydrogenase activity was measured using a protocol based on that of Malamy \& Horecker (1961). The reagent mixture contained $20 \mathrm{mM}$ Tris $/ \mathrm{HCl}$ (pH 7.7), $10 \mathrm{mM} \mathrm{MgCl}, 0.8 \mathrm{mM} \mathrm{NADP}^{+}$ and $5 \mathrm{mM}$ sodium glutamate (final concentrations). Initial rates of reaction were calculated by using an extinction coefficient of $6200 \mathrm{M}^{-1} \mathrm{~cm}^{-1}$ for NADPH (Dawson et al., 1986). Cellobiosidase activity was measured spectrophotometrically using the cellotriose analogue $p$-nitrophenyl cellobioside as substrate, as described by Huang \& Forsberg (1988). Succinate dehydrogenase activity was measured as described by Dickie \& Weiner (1979) by monitoring the phenazine methosulfate coupled reduction of 3(4,5-dimethylthiazolyl-2)-2,5-diphenyltetrazolium bromide (MTT). Initial rates of reaction were calculated by using an extinction coefficient of $17000 \mathrm{M}^{-1} \mathrm{~cm}^{-1}$ for reduced MTT (Weiner, 1974).

Nuclease purification. After growth at $37^{\circ} \mathrm{C}$ for $18 \mathrm{~h}$, cells from 121 medium were collected under aerobic conditions by centrifugation at $13200 \mathrm{~g}$ for $20 \mathrm{~min}$ at $4^{\circ} \mathrm{C}$. The resultant pellets were pooled and the periplasmic contents were released as described above. The concentrated periplasmic fraction was ultracentrifuged at $100000 \mathrm{~g}$ for $120 \mathrm{~min}$ at $4{ }^{\circ} \mathrm{C}$. The supernatant was recovered and brought to $80 \%$ saturation with solid ammonium sulfate; the $\mathrm{pH}$ was maintained near neutrality with the addition of $1 \mathrm{M} \mathrm{NH}_{4} \mathrm{OH}$ as needed. The preparation was stirred on ice for $45 \mathrm{~min}$, after which proteins were recovered by centrifugation at $13200 \mathrm{~g}$ for $60 \mathrm{~min}$ at $4{ }^{\circ} \mathrm{C}$. The supernatant was discarded and protein pellets were resuspended in TE buffer $\left(20 \mathrm{mM}\right.$ Tris $/ \mathrm{HCl}, \mathrm{pH} 7 \cdot 3$ at $4{ }^{\circ} \mathrm{C}$, $0.5 \mathrm{mM}$ EDTA) and mixed until the proteinaceous material was in suspension. This protein solution was concentrated and desalted (via buffer exchange) through a PM-10 Amicon membrane. The concentrated, desalted protein solution was applied to a chromatography column $(20 \times 1.5 \mathrm{~cm})$ containing Heparin Sepharose CL-6B (Amersham Pharmacia Biotech) that had previously been equilibrated with TE buffer. Protein was eluted from the medium with a $300 \mathrm{ml} 0 \cdot 2-0 \cdot 9 \mathrm{M} \mathrm{NaCl}$ 


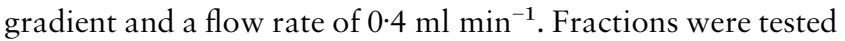
for conductivity ( $\mathrm{NaCl}$ concentration), $A_{280}$ (protein concentration), and nuclease activity as detected by an SDSPAGE-DNA zymogram (Lee et al., 1992). Fractions containing nuclease activity were pooled, concentrated and desalted via buffer exchange through a PM-10 Amicon membrane. The concentrated and desalted protein sample was applied to a $20 \times 1.5 \mathrm{~cm}$ chromatography column containing hydroxyapatite Bio-Gel HTP (Bio-Rad) equilibrated with $20 \mathrm{mM}$ potassium phosphate buffer $\left(\mathrm{pH} 7 \cdot 3\right.$ at $\left.4{ }^{\circ} \mathrm{C}\right)$. Proteins were eluted using a $300 \mathrm{ml} 0 \cdot 1-0.6 \mathrm{M}$ potassium phosphate buffer $(\mathrm{pH} 7 \cdot 3)$ gradient and a flow rate of $0.4 \mathrm{ml} \mathrm{min}^{-1}$. Fractions containing nuclease activity were pooled and desalted using a PM-10 Amicon membrane and the phosphate buffer was exchanged with the TE buffer.

The protein sample was applied to a $90 \times 1 \mathrm{~cm}$ column containing Sephadex G-75 (Amersham Pharmacia Biotech) that had previously been equilibrated in the TE buffer. Proteins and buffer were carried through the column under the force of gravity with a flow rate of $0.04 \mathrm{ml} \mathrm{min}^{-1}$. Appropriate fractions were pooled and concentrated and this final preparation was assessed for purity by SDS-PAGE (Laemmli, 1970) followed by staining with Coomassie brilliant blue R-250 and by silver staining. Protein samples were stored on ice at $4{ }^{\circ} \mathrm{C}$ or were supplemented with $25 \%(\mathrm{w} / \mathrm{v})$ glycerol and stored at $-20{ }^{\circ} \mathrm{C}$.

Determination of molecular mass by size-exclusion chromatography. DNase A was applied to a $90 \times 1 \mathrm{~cm}$ chromatography column containing Sephadex G75 (Amersham Pharmacia Biotech) previously equilibrated with TE buffer. The column was calibrated using a Low Molecular Mass Gel Filtration Calibration Kit (Amersham Pharmacia Biotech) according to the manufacturer's directions. Proteins were carried through the column under the force of gravity with a flow rate of $0 \cdot 04 \mathrm{ml} \mathrm{TE} \mathrm{min}^{-1}$.

DNase A kinetic characteristics. To calculate values for $K_{\mathrm{m}}$ and $V_{\max }$, initial velocities were measured via the Kunitz assay at various DNA concentrations. Data were fitted to the Michaelis-Menten equation and values for $K_{\mathrm{m}}$ and $V_{\max }$ were estimated using a SigmaPlot 2.01 (SPSS Science) curve-fitting program that fits data to non-linear functions directly by nonlinear regression (Kuo, 1992).

To compare the parameters of $K_{\mathrm{m}}$ and $K_{\text {cat }}$ for DNase A to various other nucleases, $K_{\mathrm{m}}$ values were converted from $\mu \mathrm{g} \mathrm{ml}^{-1}$ to $\mu \mathrm{M}$ internucleotide bonds (Hale et al., 1993) by using a mean molar mass of $330 \mathrm{~g} \mathrm{~mol}^{-1} \mathrm{nt}^{-1}$. $V_{\max }$ values were converted to $K_{\text {cat }}$ by assuming the molar mass per nucleotide was $330 \mathrm{~g} \mathrm{~mol}^{-1}$ and that a change in absorbance of 0.3 accompanied the degradation of $0.05 \mathrm{mg}$ DNA. The molecular mass of DNase A was assumed to be $33 \mathrm{kDa}$. $K_{\text {cat }}$ was obtained from the general expression $V_{\max }=K_{\text {cat }}\left[\mathrm{E}_{0}\right]$.

Influence of disulfide bond formation on DNase $A$ activity. Equivalent amounts of enzyme in $50 \mathrm{mM}$ Tris $/ \mathrm{HCl}(\mathrm{pH} \mathrm{8.0)}$ were reduced with $25 \mathrm{mM}$ DTT for $30 \mathrm{~min}$ at $37^{\circ} \mathrm{C}$ with or without a subsequent supplementation of $30 \mathrm{mM}$ iodoacetamide and further incubation for $15 \mathrm{~min}$ at room temperature. Identical samples were either untreated (control) or treated with $30 \mathrm{mM}$ iodoacetamide alone and incubated for $15 \mathrm{~min}$ at room temperature. After incubation, excess reagents in all samples were removed by centrifugation through a $10 \mathrm{kDa}$ molecular mass cut-off membrane (PM-10, Amicon). Protein concentrations were determined and samples were adjusted to the appropriate volume in buffer and assayed for activity via the Kunitz assay. Aliquots of each sample were also resolved by SDS-PAGE and the electrophoretic mobilities of the treated proteins were compared with those of reduced and oxidized standards of DNase A.

Immunological techniques. Polyclonal antiserum was raised against purified antigen by injection into a New Zealand White rabbit. Antibodies specific for DNase A were purified from serum by a method modified from that of Olmstead (1986). Antigen was detected by either the alkaline phosphatase detection system (Bio-Rad) as described by the manufacturer or by a horseradish peroxidase based SuperSignal Ultra (Pierce) chemiluminescence system as described by the manufacturer.

Gel electrophoresis. SDS-PAGE was conducted using $12 \%$ polyacrylamide gels (Laemmli, 1970) at $4{ }^{\circ} \mathrm{C}$ and $120 \mathrm{~V}$ for $1 \mathrm{~h}$. When SDS-PAGE was conducted under oxidizing conditions, reducing agents were omitted from the electrophoresis sample buffer and samples were not heated. For molecular mass determination via SDS-PAGE, Broad-Range molecular mass protein standards (Bio-Rad) were used. Standard reduced DNase A was produced by treatment of the enzyme with $10 \mathrm{mM}$ DTT for $30 \mathrm{~min}$ followed by addition of iodoacetamide to a final concentration of $25 \mathrm{mM}$ and a further incubation of $15 \mathrm{~min}$ at $37^{\circ} \mathrm{C}$. Excess reagents were removed by filtration. DNase A purified under ambient atmospheric conditions was obtained as an oxidized species and this was used as the standard oxidized protein. Immediately before electrophoresis, appropriate volumes of each standard were mixed together and further mixed with an equal volume of sample buffer lacking reducing agent. When applied to a single lane and electrophoresed, two bands with apparent molecular masses of $33 \mathrm{kDa}$ and approximately $29 \mathrm{kDa}$ were detected, representing the reduced and oxidized forms of DNase A, respectively.

SDS-PAGE-DNA zymograms were conducted as above except that $100 \mu \mathrm{g}$ salmon sperm DNA ml ${ }^{-1}$ (final concentration) (Difco Laboratories) was added to the gel preparation before polymerization and reducing agents were omitted from the sample-loading buffer. The samples were not heated prior to loading on the gel. After electrophoresis at $120 \mathrm{~V}$, gels were washed and incubated as described by Lee et al. (1992). The development of activity was detected by staining the gel in an aqueous solution of ethidium bromide $\left(0.5 \mu \mathrm{g} \mathrm{ml}^{-1}\right)$ for $20 \mathrm{~min}$, destaining the gel for $20 \mathrm{~min}$ in incubation buffer and viewing the gel over a UV transilluminator. Non-fluorescent bands against a fluorescent background indicated enzymic activity. Images of the electrophoretic gels were captured using a Gel-Doc 1000 gel documentation system (Bio-Rad) and were subsequently scanned on a ScanJet 6100C scanner (Hewlett Packard).

Protein determination. Protein concentration was determined either by the method described by Bradford (1976) or the bicinchoninic acid protein assay (Smith et al., 1985) using commercially available reagents from either Bio-Rad or Sigma, respectively. Bovine serum albumin was used as the reference protein.

Determination of in vivo redox state of DNase A. A $150 \mathrm{ml}$ culture of F. succinogenes was grown for $24 \mathrm{~h}$. At time points roughly corresponding to lag phase, exponential growth phase, late exponential phase, early stationary phase and decline phase, aliquots of cell suspension were withdrawn from the bulk culture and total cell protein concentrations were determined using the bicinchoninic acid method. Within each sample the redox state of DNase A was assessed essentially as described by Kishigami et al. (1995), except that 
all manipulations prior to electrophoresis were conducted in an anaerobic chamber. DNase A was detected by chemiluminescent Western blotting. The relative mobility of DNase A in each sample was compared with reduced and oxidized standards of DNase A. Redox measurements of growth media were made with an Orion SA250 $\mathrm{pH}$ meter equipped with a Corning Redox Combo w/RJ redox probe (Orion Research).

\section{RESULTS AND DISCUSSION}

\section{Cell fractionation and nuclease localization}

After subcellular fractionation, most of the glutamate dehydrogenase activity $(73 \%$ of the activity recovered from the subcellular fractions) and all of the succinate dehydrogenase activity was detected in the cytoplasm and cytoplasmic membrane fraction, respectively (Table 1). Cellodextrinase, which was known to be a periplasmic enzyme (Gong \& Forsberg, 1993), partitioned with the periplasmic fraction. These data indicate that the cell fractionation procedure was relatively efficient.
Testing of each fraction for nuclease activity showed that almost all was present in the periplasmic fraction (Table 1). When fractions were probed with DNase Aspecific antiserum, the major signal was detected in the periplasmic fraction and a much weaker signal was detected in the cytoplasm (not shown). These data demonstrate that DNase $\mathrm{A}$ is a periplasmic protein. This location may allow the nuclease to adequately carry out its presumed function as a barrier to the uptake of foreign DNA by intercepting and degrading the polymer before passage into the cytoplasm occurs.

\section{Nuclease purification and molecular mass determination}

Table 2 shows the purification process as monitored by nuclease assays and total protein. The enzyme was purified 550-fold. From 121 cell culture utilized in this experiment, $100 \mu \mathrm{g}$ pure protein was obtained. Over the course of this work $130 \mathrm{l}$ overnight culture were

Table 1. Distribution of nuclease activity, glutamate dehydrogenase, succinate dehydrogenase, cellodextrinase and protein in subcellular fractions

ND, Not detected. Values in parentheses are percentage activity expressed relative to that of the whole cell lysate that is taken as $100 \%$. Standard errors less than $0 \cdot 1$ are not reported.

\begin{tabular}{|c|c|c|c|c|c|}
\hline \multirow[t]{2}{*}{ Fraction } & \multicolumn{5}{|c|}{ Distribution of enzyme activity or protein concentration $(\%)$} \\
\hline & Nuclease* & $\begin{array}{c}\text { Glutamate } \\
\text { dehydrogenase } \dagger\end{array}$ & $\begin{array}{c}\text { Succinate } \\
\text { dehydrogenase } \dagger\end{array}$ & Cellodextrinase $†$ & $\begin{array}{l}\text { Protein } \\
\left(\mathrm{mg} \mathrm{m}^{-1}\right)\end{array}$ \\
\hline ECCF $\neq$ & $34(<1)$ & $\mathrm{ND}(0)$ & $\mathrm{ND}(0)$ & $\mathrm{ND}(0)$ & $0 \cdot 2(4)$ \\
\hline Outer membrane & $60(1)$ & $\mathrm{ND}(0)$ & $\mathrm{ND}(0)$ & ND $(0)$ & $0 \cdot 1(3)$ \\
\hline Periplasm & $4860(100)$ & $58 \pm 3(24)$ & $\mathrm{ND}(0)$ & $362 \pm 14(71)$ & $1.5(29)$ \\
\hline Cytoplasmic membrane & $61(1)$ & $8 \pm 1(4)$ & $244 \pm 2(108)$ & $17 \pm 3(3)$ & $1 \cdot 1(22)$ \\
\hline Cytoplasm & $541(11)$ & $182 \pm 20(60)$ & $\mathrm{ND}(0)$ & $124 \pm 3(21)$ & $1 \cdot 7(34)$ \\
\hline Whole cell lysate & $4860(100)$ & $300 \pm 30(100)$ & $225 \pm 10(100)$ & $580 \pm 10(100)$ & $5 \cdot 0(100)$ \\
\hline
\end{tabular}

* Nuclease specific activity is the inverse of the titre obtained in the microtitre plate assay.

†Enzyme activity is the mean \pm standard error of the total activity.

$\ddagger$ Extracellular culture fluid.

Table 2. Purification of the nuclease

Total activity is expressed as $\Delta A_{260}$ units $\min ^{-1}$ and specific activity was $\Delta A_{260}$ units $\mathrm{min}^{-1}$ $(\mathrm{mg} \text { protein })^{-1}$.

\begin{tabular}{|lccc|}
\hline Step & $\begin{array}{c}\text { Total } \\
\text { activity* }\end{array}$ & $\begin{array}{c}\text { Total } \\
\text { protein }(\mathbf{m g})\end{array}$ & $\begin{array}{c}\text { Specific activity } \\
{\left[\mathbf{U}(\mathbf{m g} \text { protein })^{-1}\right]}\end{array}$ \\
\hline Periplasmic precipitate & 603 & 861 & $0 \cdot 7$ \\
Heparin sepharose & $292 \cdot 5$ & 37 & $7 \cdot 9$ \\
Hydroxyapatite & 198 & 8 & $24 \cdot 8$ \\
Gel filtration & $49 \cdot 5$ & $0 \cdot 1$ & 495 \\
\hline
\end{tabular}

* Assays were conducted with $25 \mu \mathrm{g} \mathrm{DNA} \mathrm{ml}{ }^{-1}$ at $25^{\circ} \mathrm{C}$. 


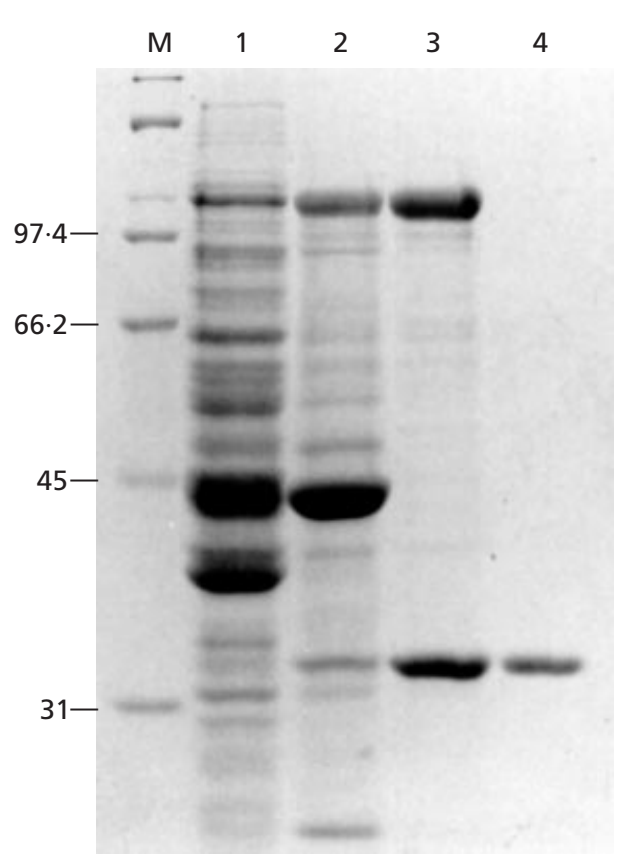

Fig. 1. SDS-PAGE and Coomassie brilliant blue staining of protein samples after each step in the purification process. Lane $\mathrm{M}$, broad range molecular mass markers (kDa); lane 1, periplasmic proteins; lane 2, after heparin Sepharose chromatography; lane 3, after hydroxyapatite gel chromatography; lane 4, after Sephadex G75 size exclusion chromatography. Approximately $3 \mu \mathrm{g}$ purified DNase A was loaded into lane 4. Note: all protein samples were mixed with the Laemmli sample buffer containing SDS and $\beta$-mercaptoethanol and heated prior to electrophoresis, a process that reduces disulfide bonds.

processed for a final yield of $1 \mathrm{mg}$ pure protein. Fig. 1 demonstrates the purification process as monitored by SDS-PAGE after treatment of protein preparations with sample buffer containing $\beta$-mercaptoethanol and staining with Coomassie brilliant blue R-250. Silver staining of the pure preparation detected a single band of $33 \mathrm{kDa}$, demonstrating purification to homogeneity. The molecular mass of DNase A by size exclusion chromatography on Sephadex G-75 was estimated to be $26 \mathrm{kDa}$, which is similar to the $29 \mathrm{kDa}$ monomeric mass of DNase A inferred from SDS-PAGE, suggesting that the enzyme exists as a monomer in solution.

\section{Characterization of DNase A}

The optimum concentration of $\mathrm{Mg}^{2+}$ ions for maximum activity in the Kunitz assay was broad and extended from approximately 10 to $30 \mathrm{mM} \mathrm{MgCl}_{2}$; reagent mixtures were usually supplemented with $20 \mathrm{mM}$ $\mathrm{MgCl}_{2}$. No activity was exhibited in the absence of added cation. The rate of DNA depolymerization was insensitive to whether the conjugate anion to $\mathrm{Mg}^{2+}$ was $\mathrm{Cl}^{-}$or $\mathrm{SO}_{4}^{2-}$ and $20 \mathrm{mM} \mathrm{Mn}{ }^{2+}$ resulted in a $2 \cdot 5$-fold greater specific activity $\left[1550 \pm 250 A_{260}\right.$ units $\min ^{-1}(\mathrm{mg}$ protein $)^{-1}$ ] than that exhibited with $20 \mathrm{mM} \mathrm{Mg}^{2+}$ $\left.\left[600 \pm 48 A_{260} \text { units } \min ^{-1} \text { (mg protein) }\right)^{-1}\right] . \mathrm{Ca}^{2+}$ did not

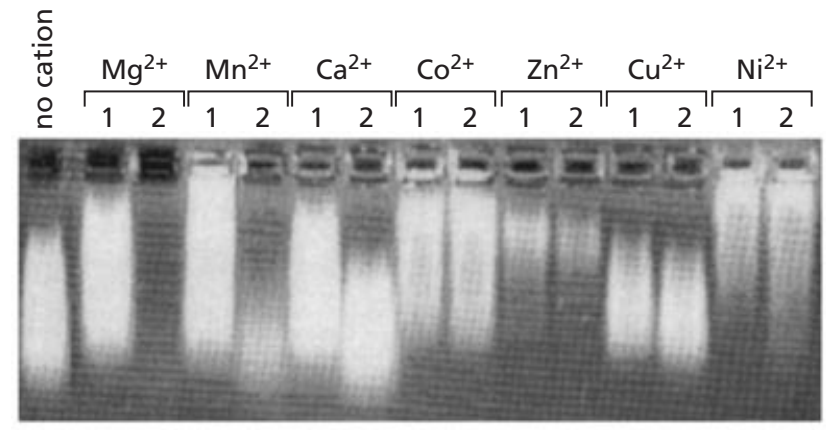

Fig. 2. Nuclease activity in the absence of cation (no cation) and in the presence of various cations of chloride salts was detected by agarose gel electrophoresis of the reaction products. Equivalent amounts of herring sperm DNA was supplemented with $5 \mathrm{mM}$ salt (shown above each pair of lanes) and incubated in the absence (lanes 1) or presence (lanes 2) of $0.25 \mu \mathrm{g}$ DNase A for $3 \mathrm{~min}$ prior to stopping the reaction by addition of $50 \mathrm{mM}$ EDTA and electrophoresis. Remaining substrate was visualized by ethidium bromide staining after electrophoresis. Undigested DNA is visible as a high-molecularmass smear in the gel, except in the presence of zinc or copper salts (see text).

appreciably stimulate activity. When other transition divalent cations were used to substitute as required cofactors in the catalytic mechanism of DNase A using the Kunitz assay, uninterpretable results were obtained. For example, supplementation of the assay mixture with $5 \mathrm{mM} \mathrm{CoCl}_{2}$ led to a rapid, linear, enzyme-independent increase in $A_{260}$ - a condition that, without proper controls, could be mistaken for enzyme activity. We therefore confirmed the spectrum of stimulatory cations in the Kunitz assay by using an agarose-gel-based assay and visually assessing the degradation of DNA substrate after exposure to nuclease in the presence of various cations. In the absence of cation (Fig. 2) there was little nuclease-dependent substrate depletion as indicated by the perseverance of the high molecular mass DNA smear. Supplementation with $\mathrm{Mg}^{2+}$ and nuclease (lane 2 of the magnesium treatment) resulted in complete depolymerization of the DNA in contrast to that observed in the control treatment where only the $\mathrm{Mg}^{2+}$ was added (lane 1 of the magnesium treatment). For $\mathrm{Co}^{2+}, \mathrm{Ni}^{2+}, \mathrm{Cu}^{2+}$ and $\mathrm{Zn}^{2+}$, the appearance of the DNA smear is similar for both the control treatment (salt only; lanes 1) and the test treatment (salt and nuclease; lanes 2). Therefore, supplementation with these salts does not lead to enzyme-dependent degradation of the DNA. When nuclease is added to the DNA treated with calcium cations (lane 2), there appears to be a small decrease in polymer size but this effect is similar to when the DNA is exposed to nuclease in the absence of any cation. When the nuclease was tested for activity via the Kunitz assay in the absence of added cation or in the presence of calcium, there was a very small, almost negligible increase in absorbance, perhaps indicating very low levels of basal activity under these conditions. Interestingly, the gel-based assay demonstrated that $\mathrm{Mn}^{2+}$ stimulated activity less than did $\mathrm{Mg}^{2+}$, in contrast 


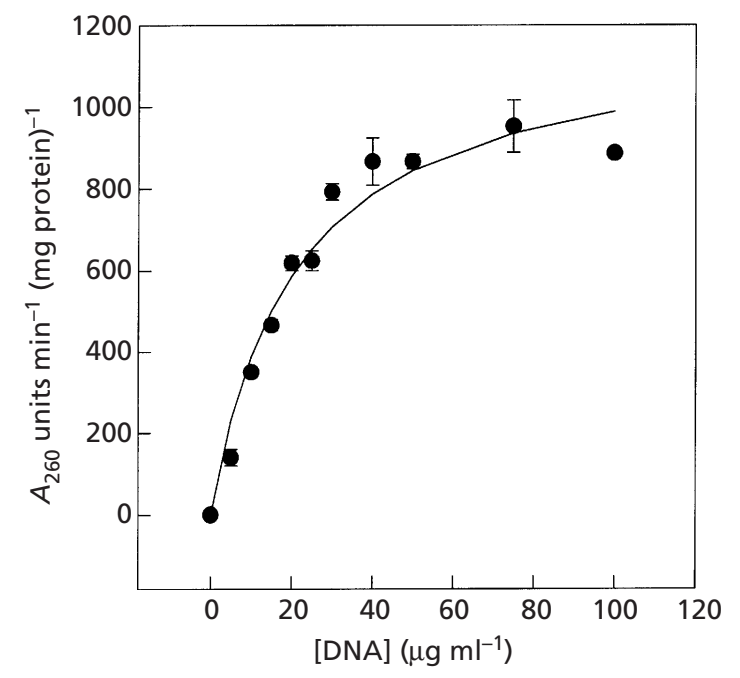

Fig. 3. Effect of substrate concentration on DNase A activity. Nuclease activity on herring testes DNA was monitored by the Kunitz assay. Line was fitted to data and values for $K_{\mathrm{m}}$ $\left(20 \pm 4 \mu \mathrm{g} \mathrm{DNA} \mathrm{ml}{ }^{-1}\right)$ and $V_{\max }\left[1192 \pm 88 A_{260}\right.$ units $\min ^{-1}(\mathrm{mg}$ protein $)^{-1}$ ] were calculated by SigmaPlot curve fitting program using non-linear regression. Mean values and standard errors were calculated from three replications.

to the data generated using the Kunitz assay. The failure to corroborate the Kunitz assay data by visual detection of DNA degradation as monitored by ethidium bromide staining $\left(\right.$ for $\mathrm{Mn}^{2+}$ ) may be a consequence of the rather well-documented effects that certain (especially transition) cations have on DNA structure (for examples, see Anderson et al., 1971; Kejnovsky \& Kypr, 1998; Langlais et al., 1990) and therefore its UV absorption characteristics in the Kunitz assay. In Fig. 2, DNA supplemented with $\mathrm{Cu}^{2+}$ and $\mathrm{Zn}^{2+}$ [either without (lane 1) or with (lane 2) added nuclease] also appeared differently after electrophoresis and staining, perhaps suggesting a structural change in the DNA. Obviously, caution is needed when assessing the ability of a metal to act as a co-factor with any nuclease assay. Our data indicates that DNA depolymerization does not appreciably take place in the absence of magnesium or manganese, or in the presence of calcium, nickel, zinc or copper salts. With regard to the latter salts, we did not differentiate whether these ions are simply not permissible co-factors, are inhibitory to the nuclease or their effect on DNA renders the substrate resistant to cleavage by nuclease.

The optimal temperature for activity was demonstrated to be approximately $25^{\circ} \mathrm{C}\left[810 \pm 10 A_{260}\right.$ units min $^{-1}$ $(\text { mg protein })^{-1}$ ] with greater than $75 \%$ of the maximum activity at both 20 and $33^{\circ} \mathrm{C}$. At a temperature corresponding to the in situ rumen temperature of about $39^{\circ} \mathrm{C}$, the enzyme retained only about $33 \%$ of the activity exhibited at $25^{\circ} \mathrm{C}$. This may reflect differences between the in vivo and in vitro behaviour of the enzyme but this enzyme is one of several $F$. succinogenes hydrolases, for example, endoglucanase G (Iyo \& Forsberg, 1999), that have curiously low optimum temperatures for activity in vitro.

Enzymic activity was at the maximum at a $\mathrm{pH}$ of $7 \cdot 0$, but retained greater than $90 \%$ of that activity between $\mathrm{pH}$ values of $6 \cdot 5$ and $8 \cdot 7$.

$\mathrm{NaCl}$ and $\mathrm{KCl}$ were used to assess the effects of monovalent cations on nuclease activity. Responses to both chemicals were similar and neither salt significantly stimulated activity. Activity remained constant between 0 and $75 \mathrm{mM}$ but $100 \mathrm{mM}$ was slightly inhibitory and at a concentration of $300 \mathrm{mM}$ the enzyme exhibited less than $20 \%$ of its activity in the absence of these salts.

The rate of DNA depolymerization catalysed by DNase $A$ as a function of substrate concentration followed Michaelis-Menten kinetics (Fig. 3). A $K_{\mathrm{m}}$ value of $20 \pm 4 \mu \mathrm{g}$ DNA ml ${ }^{-1}$ and a $V_{\max }$ value of $1192 \pm 88 A_{260}$ units $\mathrm{min}^{-1}$ (mg protein $)^{-1}$ were estimated from the curve and these values were converted to a $K_{\mathrm{m}}$ of $61 \pm 12 \mu \mathrm{M}$ and a $K_{\text {cat }}$ of $330 \pm 24 \cdot 5 \mathrm{~s}^{-1}$, respectively. These values are compared with previously published kinetic quantities for other nucleases in Table 3. DNase

Table 3. Comparison of the catalytic properties of DNase A with other endonucleases

Values for kinetic parameters of other enzymes are from Friedhoff et al. (1996) and Meiss et al. (1998).

\begin{tabular}{|c|c|c|c|c|c|c|}
\hline Enzyme & $\begin{array}{l}\text { Substrate } \\
\text { DNA }\end{array}$ & $\begin{array}{c}\boldsymbol{K}_{\mathrm{m}} \\
(\boldsymbol{\mu M})^{*}\end{array}$ & $K_{\mathrm{cat}}\left(\mathrm{s}^{-1}\right)$ & $\begin{array}{c}K_{\mathrm{cat}} / K_{\mathrm{m}}\left(\mathrm{s}^{-1}\right. \\
\left.\boldsymbol{\mu} \mathbf{M}^{-1}\right)\end{array}$ & $\begin{array}{l}\text { Preferred } \\
\text { co-factor }\end{array}$ & Reference \\
\hline $\begin{array}{l}\text { F. succinogenes } \\
\text { DNase A }\end{array}$ & Herring testes & $61 \pm 12$ & $330 \pm 25$ & $5 \cdot 4$ & $\mathrm{Mg}^{2+}$ & This work \\
\hline $\begin{array}{l}\text { S. marcescens } \\
\text { NucA }\end{array}$ & Salmon testes & $53 \cdot 8 \pm 8$ & $2100 \pm 63$ & 54 & $\mathrm{Mg}^{2+}$ & Friedhoff et al. (1996) \\
\hline $\begin{array}{l}\text { Bovine pancreas } \\
\text { DNase I }\end{array}$ & Calf thymus & 109 & 176 & $1 \cdot 6$ & $\mathrm{Mg}^{2+}$ & Doherity et al. (1995) \\
\hline $\begin{array}{l}\text { Staphylococcus } \\
\text { nuclease }\end{array}$ & Salmon sperm & $48 \pm 11$ & $730 \pm 76$ & 15 & $\mathrm{Ca}^{2+}$ & Poole et al. (1991) \\
\hline Anabaena NucA & Herring sperm & 164 & 1921 & $11 \cdot 7$ & $\mathrm{Mn}^{2+}, \mathrm{Co}^{2+}$ & Meiss et al. (1998) \\
\hline
\end{tabular}

*Determined using the Kunitz assay. 


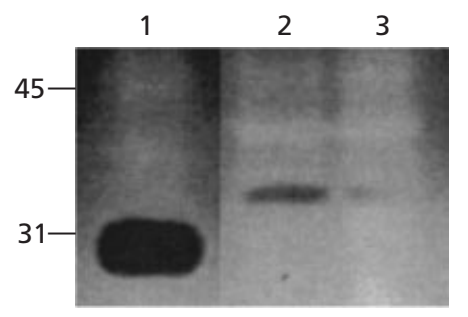

Fig. 4. Differential migration of oxidized and reduced $D$ Nase $A$ in an SDS-PAGE-DNA zymogram. Before electrophoresis, equivalent aliquots of French Press-disrupted whole cells were incubated for $30 \mathrm{~min}$ at $37^{\circ} \mathrm{C}$ in sample loading buffer lacking a reducing agent (lane 1 ) or in sample buffer supplemented with either $1.4 \mathrm{M} \beta$-mercaptoethanol (lane 2) or $0.2 \mathrm{M}$ dithiothreitol (lane 3). Positions of molecular mass markers $(\mathrm{kDa})$ are indicated. Only one band of enzyme activity was observed in each of the three treatments.

A had a lower catalytic efficiency than the $S$. marcescens NucA, but a more similar efficiency to the Staphylococcus and Anabaena nucleases.

\section{Detection and importance of disulfide bonds in DNase A}

Beyond efficient secretion out of the cytoplasm, F. succinogenes cells must possess a means of keeping the nuclease inactive while in the cytoplasmic compartment since DNase A degrades host genomic DNA. The extracellular nuclease of $S$. marcescens has been shown to require disulfide bonds for catalytic activity (Ball et al., 1992). Since the cytoplasm of $S$. marcescens has a low redox potential, the enzyme is inactive and consequently the cells survive in the presence of intracellular intact, but inactive enzyme (Ball et al., 1992; Benedik \& Strych, 1998). It seemed possible that the inability to form disulfide bonds in the reducing cytoplasm could also explain why the nuclease is not lethal in $F$. succinogenes. Experiments were therefore designed to determine whether DNase A possessed disulfide bonds and whether these bonds were required for nucleolytic activity. Whole cell lysates were incubated in SDS-PAGE sample buffer supplemented with either DTT or $\beta$ mercaptoethanol, or in sample buffer lacking reducing agents and were subsequently resolved by SDS-PAGE and nuclease activity detected by DNA zymogram analysis (Fig. 4). Non-fluorescent bands indicating nuclease activity developed slowly after treatment with reducing agent and migrated with an apparent molecular mass of $33 \mathrm{kDa}$. Non-reduced lysate developed a nonfluorescent band much more quickly and this band migrated with an apparent molecular mass of 29$30 \mathrm{kDa}$. This mobility shift is indicative of one or more disulfide bonds in DNase A.

Purified DNase A was subsequently tested for activity in the Kunitz assay before $\left[620 A_{260}\right.$ units $\min ^{-1}$ (mg protein) ${ }^{-1}$ ] and after treatment with $25 \mathrm{mM}$ DTT to determine whether disulfide bonds were required for activity. The treatment decreased the activity of the enzyme by $86 \%$. Reduced proteins can be alkylated with iodoacetamide to modify free thiol groups such that disulfides cannot be re-acquired in a protein after removal of the reducing agent (Kishigami et al., 1995). Alkylation alone of DNase A caused only an $8 \%$ decrease in activity. When the enzyme was alkylated after reduction, the activity of the enzyme was decreased by $96.6 \%$ as compared to that of the unreduced, unalkylated enzyme. Aliquots of treated and untreated samples were resolved by SDS-PAGE to compare the migration of DNase A with oxidized and reduced controls. The migration end points of each sample matched expectations given the treatment applied (i.e. oxidized protein was $29 \mathrm{kDa}$ and the reduced protein was $33 \mathrm{kDa}$ ) (not shown). Therefore, DNase A is nearly inactive in the reduced state.

\section{Redox state of DNase A in vivo}

The initial observation that DNase A was inactivated after reduction by either $\beta$-mercaptoethanol or dithiothreitol led to the question of whether the enzyme in growing cells might be present in a reduced and therefore inactive state. This seemed plausible since the cysteine residues within DNase could be reduced because of the combination of a reducing agent in the medium and the well poised low redox potential of the medium during growth. Kobayashi \& Ito (1999) indicated that inclusion of dithiothreitol in the culture medium of Escherichia coli causes reduction of the periplasmic thiol:disulfide oxidoreductase (DsbA). Similarly, the cysteine included in the medium as a reducing agent might diffuse into the periplasm of $F$. succinogenes and reduce disulfides.

Redox measurements of uninoculated anaerobic media and of $F$. succinogenes cultures showed that the $E_{\mathrm{h}}$ varied from approximately $-207 \mathrm{mV}$ for freshly prepared uninoculated medium to approximately $-327 \mathrm{mV}$ after $24 \mathrm{~h}$ growth. We therefore sought to determine whether DNase A accumulated in a reduced or oxidized form in vivo, especially under the stringent reducing conditions ambient after several hours of cell growth in the anaerobic medium. Aliquots of cells were removed from a growing culture at the time points indicated in Fig. 5(a). The whole-cell proteins were immediately precipitated with TCA and modified by iodoacetamide in order to trap reduced proteins. Equivalent amounts of total cell protein from each time point were resolved by SDS-PAGE. DNase A was detected by chemiluminescent Western immunoblotting and it was observed to migrate to a position of $29 \mathrm{kDa}$, similar to that of an oxidized DNase A control (Fig. 5b). Therefore in spite of the reducing potential of the medium, $F$. succinogenes cells possessed the ability to oxidize periplasmic DNase A molecules throughout 24 h growth in batch culture (Fig. 5) even as the culture medium becomes increasingly and strongly reducing. This suggests that an oxidizing pathway for disulfide bond formation is not compromised by the extremely low redox potential exhibited in the culture medium during 
(a)

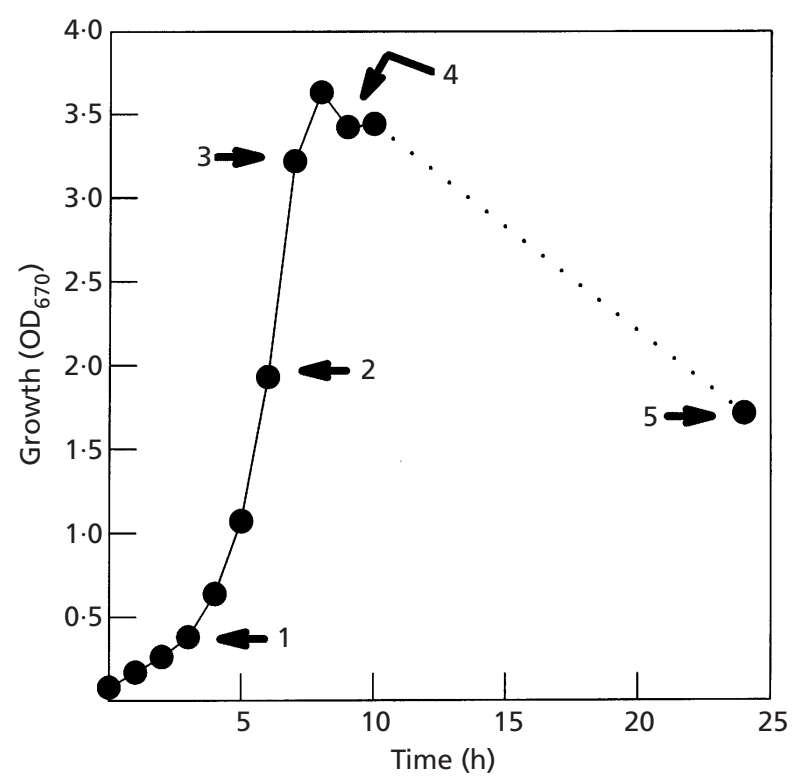

(b)

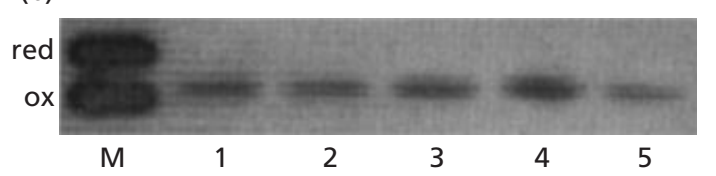

Fig. 5. Redox state of DNase $A$ accumulated in vivo during growth. (a) Total cellular proteins extracted from a growing culture (time points 1-5) were precipitated with trichloroacetic acid and treated with iodoacetamide to trap free thiol groups. (b) Precipitated and alkylated proteins from cells removed at each time point in Fig. $5 \mathrm{a}(1-5)$ were resuspended and resolved by SDS-PAGE, transferred to a nitrocellulose membrane and probed with affinity-purified anti-DNase $A$ antiserum and goat anti-rabbit horseradish peroxidase conjugated antibodies. Mobility of DNase A sampled from each stage of growth was detected by chemiluminescence and compared with the mobility of reduced and oxidized standards of DNase A (M).

growth. More importantly, this establishes that $F$. succinogenes possesses a periplasmic mechanism of oxidatively forming and maintaining disulfide bonds in secreted proteins since all proteins initially exist in the cytoplasm in a reduced form. These results provide the first instance of demonstrating in vivo periplasmic disulfide bond formation in a strictly anaerobic bacterium though we suspect that the activity is as widespread in this class of bacteria as it seems to be in the facultative and aerobic bacteria.

During growth under aerobic conditions, molecular oxygen is presumed to provide the ultimate oxidizing potential that drives disulfide bond formation, and in the absence of oxygen other common electron acceptors presumably fulfil this role. Clearly, under the anaerobic and reducing conditions typical for the growth of strict anaerobes, a different pathway for the disposal of electrons must be imagined. Bader et al. (1999) have recently shown that when a strain of E. coli with null mutations in cytochrome $b d$ and $b o$ oxidases was grown under anaerobic conditions in a GasPak Anaerobic System (albeit with no added reducing agent) to avoid interference from trace quantities of oxygen and with glucose as the primary carbon source, the periplasmic indicator protein $\beta$-lactamase was maintained in an oxidized form. This and related data documented that in E. coli growing under anaerobic conditions, the DsbADsbB system shuttles electrons via menaquinone to terminal acceptors such as fumarate.

F. succinogenes also possesses a membrane-associated $\mathrm{NADH}$-dependent fumarate reductase that transfers electrons from a membrane receptor, presumably menaquinone, to fumarate with the rather prolific formation of the reduced product succinate (Meinhardt \& Glass, 1994). Therefore, this strict anaerobe probably possesses a disulfide bond forming mechanism analogous to that reported for E. coli and other facultatively anaerobic and aerobic bacteria. The observation that the DNase A protein remains oxidized despite a redox potential of less than $-300 \mathrm{mV}$ demonstrates that the disulfide bond forming system is functional under conditions that are quite reducing, at least in the external medium. Undoubtedly, further detailed experiments will be required to determine whether disulfide bond formation in strict anaerobes involves novel molecular adaptations to the strongly reducing environmental conditions that many other species cannot tolerate.

\section{ACKNOWLEDGEMENTS}

The research was supported by a research grant from the Natural Sciences and Engineering Research Council of Canada to C. W.F.

\section{REFERENCES}

Anderson, J. A. K., Kuntz, G. P. P., Evans, H. H. \& Swift, S. J. (1971). Preferential interaction of manganous ions with the guanine moiety in nucleosides, dinucleoside monophophates, and deoxyribonucleic acid. Biochemistry 10, 4368-4374.

Bader, M., Muse, W., Ballou, D. P., Gassner, C. \& Bardwell, J. C. A. (1999). Oxidative protein folding is driven by the electron transport system. Cell 98, 217-227.

Ball, T. K., Wasmuth, C. R., Braunagel, S. C. \& Benedik, M. J. (1990). Expression of Serratia marcescens extracellular proteins requires recA. J Bacteriol 172, 342-349.

Ball, T. K., Suh, Y. \& Benedik, J. (1992). Disulfide bonds are required for Serratia marcescens nuclease activity. Nucleic Acids Res 20, 4971-4974.

Benedik, M. J. \& Strych, U. (1998). Serratia marcescens and its extracellular nuclease. FEMS Microbiol Lett 165, 1-13.

Bradford, M. M. (1976). A rapid and sensitive method for the quantitation of microgram amounts of protein using the principle of protein-dye binding. Anal Biochem 72, 248-254.

Chesson, A. \& Forsberg, C. W. (1997). Polysaccharide degradation by rumen microorganisms. In The Rumen Microbial Ecosystem, pp. 329-381. Edited by P. Hobson \& C. Stewart. Andover: Chapman \& Hall.

Dawson, R. M., Elliot, C. D. C., Elliot, W. H. \& Jones, K. M. (1986). Vitamins and coenzymes. In Data for Biochemical Research, 3rd 
edn, pp. 122. Edited by R. M. C. Dawson, D. C. Elliot, W. H. Elliot \& K. M. Jones. Oxford: Clarendon Press.

Dickie, P. \& Weiner, J. H. (1979). Purification and characterization of membrane bound fumarate reductase from anaerobically grown Escherichia coli. Can J Biochem 57, 813-821.

Doherity, A. J., Worrall, A. F. \& Connolly, B. A. (1995). The roles of arginine 41 and tyrosine 76 in the coupling of DNA recognition to phosphodiester bond cleavage by DNase I: a study using sitedirected mutagenesis. J Mol Biol 251, 366-377.

Ellis, K. J. \& Morrison, J. F. (1982). Buffers of constant ionic strength for studying $\mathrm{pH}$-dependent processes. Methods Enzymol 87, 405-426.

Friedhoff, P., Meiss, G., Kolmes, B., Pieper, U., Gimadutdinow, O., Urbanke, C. \& Pingoud, A. (1996). Kinetic analysis of the cleavage of natural and synthetic substrates by the Serratia nuclease. Eur J Biochem 241, 572-580.

Gong, J. \& Forsberg, C. W. (1993). Separation of outer and cytoplasmic membranes of Fibrobacter succinogenes and membrane and glycogen granule locations of glycanase and cellobiase. J Bacteriol 175, 6810-6821.

Hale, S. P., Poole, L. B. \& Gerlt, J. A. (1993). Mechanism of the reaction catalyzed by staphylococcal nuclease: identification of the rate-determining step. Biochemistry 32, 7479-7487.

Halliwell, G. \& Bryant, M. P. (1963). The cellulolytic activity of pure strains of bacteria from the rumen of cattle. J Gen Microbiol 32, 441-448.

Huang, L. \& Forsberg, C. W. (1988). Purification and comparison of the periplasmic and extracellular forms of the cellodextrinase from Bacteroides succinogenes. Appl Environ Microbiol 54, 1488-1493.

Iyo, A. H. \& Forsberg, C. W. (1999). A cold-active glucanase from the ruminal bacterium Fibrobacter succinogenes S85. Appl Environ Microbiol 65, 995-998.

Kejnovsky, E. \& Kypr, J. (1998). Millimolar concentrations of zinc and other metal cations cause sedimentation of DNA. Nucleic Acids Res 26, 5295-5299.

Kishigami, S., Akiyama, Y. \& Ito, K. (1995). Redox states of DsbA in the periplasm of Escherichia coli. FEBS Lett 364, 55-58.

Kobayashi, T. \& Ito, K. (1999). Respiratory chain strongly oxidizes the CXXC motif of DsbB in the Escherichia coli disulfide bond formation pathway. EMBO J 18, 1192-1198.

Kunitz, M. (1950). Crystalline desoxyribonuclease. I. Isolation and general properties: spectrophotometric method for the measurement of desoxyribonuclease activity. J Gen Physiol 33, 349-362.
Kuo, J. (1992). About non-linear regression. In SigmaPlot Scientific Graphics Software: Transformation and Curvefitting Reference, pp. 7.1-7.2. Edited by J. Kuo. San Rafael, CA: Jandel Corporation.

Laemmli, U. K. (1970). Cleavage of structural proteins during the assembly of the head of bacteriophage T4. Nature 227, 680-685.

Langlais, M., Tajmir-Riahi, H. A. \& Savoie, R. (1990). Raman spectroscopic study of the effects of $\mathrm{Ca}^{2+}, \mathrm{Mg}^{2+}, \mathrm{Zn}^{2+}$ and $\mathrm{Cd}^{2+}$ ions on calf thymus DNA: binding sites and conformational changes. Biopolymers 30, 743-752.

Lee, S. F., Forsberg, C. W. \& Gibbins, A. M. (1992). Type-II DNA restriction modification system and an endonuclease from the ruminal bacterium Fibrobacter succinogenes S85. J Bacteriol 174, 5275-5283.

Malamy, M. \& Horecker, B. L. (1961). The localization of alkaline phosphatase in E. coli K12. Biochem Biophys Res Commun 5, 104-107.

Meinhardt, S. W. \& Glass, T. L. (1994). Characterization of the NADH dehydrogenase and fumarate reductase of Fibrobacter succinogenes subsp. succinogenes S85. Arch Microbiol 162, 329-334.

Meiss, G., Franke, I., Gimadutdinow, O., Urbanke, C. \& Pingoud, A. (1998). Biochemical characterization of Anabaena sp. strain PCC 7120 non-specific nuclease NucA and its inhibitor NuiA. Eur J Biochem 251, 924-934.

Olmstead, J. B. (1986). Analysis of cytoskeletal structures using blot-purified monospecific antibodies. Methods Enzymol 134, $467-472$.

Poole, L. B., Loveys, D. A., Hale, S. P., Gerlt, J. A., Stanczyck, S. M. \& Bolton, P. H. (1991). Deletion of the omega loop in the active site of staphylococcal nuclease: effect on catalysis and stability. Biochemistry 30, 3621-3627.

Scott, H. W. \& Dehority, B. A. (1965). Vitamin requirements of several cellulolytic bacteria. J Bacteriol 89, 1169-1175.

Smith, P. K., Krohn, R. I., Hermanson, G. T. \& 7 other authors (1985). Measurement of protein using bicinchoninic acid. Anal Biochem 150, 76-85.

Weimer, P. J. (1996). Why don't ruminal bacteria digest cellulose faster? J Dairy Sci 79, 1496-1502.

Weiner, J. H. (1974). The localization of glycerol-3-phosphate dehydrogenase in Escherichia coli. J Membr Biol 15, 1-14.

Received 6 July 2000; revised 16 October 2000; accepted 31 October 2000. 